\title{
KERAGAMAN PEMAKNAAN MURABAHAH
}

\author{
Lies Ernawati \\ liesernawati@rocketmail.com \\ STIE Widya Dharma Malang \\ Unti Ludigdo \\ Ari Kamayanti \\ Pasca Sarjana Fakultas Ekonomi dan Bisnis Universitas Brawijaya Malang
}

\begin{abstract}
The aims of this study is understand the meaning of murabahah financing by the BMT practitioners and scholars through intensionalisme hermeneutics. Intensionalisme hermeneutics used by practitioners and scholars to analyse how cultural and historical aspect of practitioners and scholars will murabaha interpretation. There were two informants from BMT Managemen, three informants from BMT customers, and four informants from scholars. The result shows, that scholars perceive murabahah as sale of mutual trust. The managements BMT perceive murabahah as a fair sale credit, mutually beneficial and have social aims. The BMT customers perceive murabahah as sale with recurring payments, easy and also has social objectives.
\end{abstract}

Key words: Meaning, murabahah, intentionalist hermeneutics.

\begin{abstract}
ABSTRAK
Penelitian ini bertujuan untuk memahami pemaknaan murabahah oleh praktisi pembiayaan murabahah pada BMT dan ulama melalui hermeneutika intensionalisme. Hermeneutika intensionalisme digunakan agar peneliti dapat memahami bagaimana aspek kultur dan historis praktisi dan ulama menginterpretasikan murabahah. Terdapat dua informan dari pihak manajemen BMT, tiga informan dari nasabah BMT dan empat informan dari ulama. Dari hasil wawancara dengan informan makna Murabahah yang diberikan ulama adalah jual beli amanah yang saling menguntungkan. Menurut manajemen BMT makna murabahah adalah jual beli kredit yang adil, saling menguntungkan dan bertujuan sosial. Menurut nasabah BMT makna murabahah adalah jual beli kredit yang murah, mudah serta bertujuan sosial.
\end{abstract}

Kata Kunci: Pemaknaan, murabahah, hermeneutika intensionalis

\section{PENDAHULUAN}

Murabahah sebagai salah satu produk lembaga keuangan syariah (LKS) sampai saat ini paling digemari.Tidak hanya oleh pengelola LKS, tetapi juga masyarakat sebagai konsumen. Hal ini karenakan murabahah dianggap sebagai produk LKS yang paling mudah transaksinya dan jelas ke untungannya. LKS merupakan bagian dari aktivitas sistem keuangan yang memberi kontribusi bagi kepentingan masyarakat secara mediatif yang menghubungkan unit surplus dan unit defisit (Fauzi, 2011).
Secara fundamental menurut Triyuwono (2011a) karakter lembaga keuangan konvensional dan LKS sangat berbeda. Perbedaan tersebut menjadi ciri khas masing-masing lembaga keuangan. Kehadiran LKS merupakan jawaban dari kegelisahan masyarakat terhadap riba yang melekat pada perbankan konvensional. Kehalalan akan riba dari sistem bunga (interest fee) inilah yang menjadi sorotan ulama. Bagai manapun juga, bunga yang ada pada perbankan konvensional merupakan tambahan atas hutang (uang) dan hal ini dalam Islam 
dilarang, karena dianggap riba (Yulianti, 2007).

Beberapa sumber hukum yang melarang adanya riba antara lain: Al-Qur'an Surat Al-Baqarah[2] ayat 275 sampai 281, yaitu melarang keras orang yang mengambil riba, dan menyatakan mereka dalam keadaan perang dengan Allah dan RasulNya. Ayat tersebut juga menetapkan perbedaan yang jelas antara perdagangan dan riba. Ayat tersebut juga memerintahkan kaum muslim untuk meninggalkan semua riba yang masih ada, memerintahkan mereka untuk hanya mengambil jumlah pokok pinjaman saja, dan membebaskan jika peminjam mengalami kesulitan.

Pada tahun 1990, para ulama mengadakan lokakarya tentang bunga bank yang dilaksanakan di Bogor. Tujuan lokakarya ini adalahuntuk memunculkan bank Islam di Indonesia sebagai jawaban atas kegelisahan masyarakat tentang bunga bank. Simpulan dari lokakarya tersebut adalah bahwa sementara belum ada bank Islam, maka bunga bank masih dibolehkan atas dasar karena darurat (Luqman, 2008). Lebih lanjut Luqman (2008) yang mengutip $\mathrm{KH}$. Hasan Basri menyatakan bahwa ada dua pandangan dalam Islam mengenai bunga bank, pertama, bunga bank adalah haram karena mengandung unsur tambahan pembayaran (ziyadah) dan tanpa risiko (muqobil). Tambahan pembayaran tersebut disyaratkan dalam perjanjian dan dapat menimbulkan pemerasan; kedua, bunga bank dianggap halal karena adanya unsur suka rela antara dua pihak, tidak ada pemerasan, dan mempunyai fungsi untuk kepentingan umum. Namun demikian dalam lokakarya tersebut dengan keras dituntut adanya bank Islam.

Bank Islam merupakan lembaga keua ngan Islam yang harus berperan aktif dalam memberi manfaat sosial-ekonomi agar dapat meningkatkan kesejahteraan masyarakat (Ali, 2012). Selain itu dalam pelaksanaan operasionalnya diwajibkan meng gunakan prinsip-prinsip syariah Islam. Prinsip syariah adalah aturan perjanjian berdasarkan hukum Islam antara lembaga keuangan dengan pihak lain untuk menyimpan dana dan atau pembiayaan kegiatan usaha, atau kegiatan lainnya sesuai dengan syariah (Luqman, 2008). Ketika bunga dilarang, Setiawan (2006) berpendapat bahwa dalam Islam mendorong para pemilik dana menjadi investor dengan menggunakan dasar pembiayaan secara Islami. Konsep investor ini merupakan pengganti konsep kreditur dalam kerangka perbankan konvensional.

Di Indonesia atas usul Majelis Ulama Indonesia (MUI) dan Ikatan Cendekiawan Muslim Indonesia ICMI serta tokoh-tokoh Islam lainnya, di bentuk bank syariah yang pertama tahun 1991 dengan nama Bank Muamalat Indonesia (BMI). Bank tersebut mulai beroperasi pada tahun 1992. Pada tahun 1992 setelah BMI berdiri, lahir Undang-undang No. 7 tahun 1992 tentang Perbankan. Namun BMI baru diresmikan pada tahun 1994 sebagai bank pertama yang ada di Indonesia yang pengelolaannya tidak berdasarkan bunga tetapi berdasarkan bagi hasil (Suparto, 2008). Berikutnya muncul kebijakan dual banking system yang diperkuat dan diperjelas dengan Undang-undang No. 10 tahun 1998 tentang perubahan atas UU Perbankan (Luqman, 2008). Kehadiran Undang-undang tersebut, menarik perhatian pihakperbankan konvensional untuk membuka unit usaha syariah. Dengan demikian perbankan syariah berkembang pesat dengan terbentuknya Bank Umum Syariah (BUS), Kantor Cabang Syariah (KCS), Unit Usaha Syariah (UUS), Bank Perkreditan Rakyat Syariah BPRS, Baitul Maal Wa Tamwil (BMT), dan Lembaga Keuangan Syariah (LKS) lainnya (Rahmawati, 2007; Luqman, 2008; Kristiyanto, 2008).

Awalnya perkembangan LKS sebagai sistem alternatif di dalam perekonomian Indonesia diragukan oleh berbagai pihak (Luqman, 2008; Kholis, 2009). Kurangnya pemahaman masyarakat tentang LKS, memunculkan anggapan bahwa LKS sama saja dengan lembaga keuangan konvensional, 
dan justru "bunganya" lebih tinggi (Kholis, 2009). Meskipun demikian, masyarakat Islam yang memahami bahwa bunga bank konvensional adalah riba, lebih merasa nyaman dengan menggunakan jasa LKS, sehingga LKS dapat terus tumbuh dan berkembang. Pertumbuhan LKS telah menembus 100 trilyun (Arsyianti dan Beik, 2010), akan tetapi pertumbuhan tersebut tidak diimbangi dengan sosialisasi dan pengetahuan masyarakat tentang LKS (Fatahullah, 2008; Kristiyanto, 2008). Namun demikian kualitas yang dimiliki LKS mampu memberi dorongan kepada pelanggan untuk menjalin ikatan yang kuat pada LKS (Astuti, 2007). Bailtul Maal Wa Tamwil (BMT) merupakan bagian dari LKS, dengan demikian selain melakukan pengumpulan dan penyaluran dana-dana non profit seperti zakat, infaq, dan shodaqah (Bailtul Maal), juga melakukan transaksi keuangan sebagaimana LKS, yaitu pengumpulan dan penyaluran dana komersial (Baitul Tamwil). Dua kegiatan tersebut menjadi bagian yang tidak terpisahkan dari BMT sebagai lembaga pendukung kegiatan ekonomi rakyat dengan berlandaskan syariah (Anggadini, 2010).

Pada tahun 1997 LKS mampu keluar dari badai likuidasi bank ketika terjadi krisis ekonomi. Kemudian pada tahun 2007 terjadi krisis financial global akibat krisis sub prime mortage yang berdampak hebat pada lembaga keuangan konvensional yang berbasis suku bunga, tetapi aman bagi LKS yang tidak berbasis suku bunga (Aisjah dan Kusumawati, 2011). Terlepas dari dampak yang muncul sebagai akibat adanya krisis, lembaga keuangan yang beroperasi dengan prinsip syariah telah mambuktikan pada dunia bahwa LKS mampu bertahan di tengah gejolak nilai tukar dan tingkat suku bunga yang tinggi (Siregar, 2002). International Monetary Fund (IMF) memperkirakan telah terjadi perlambatan pertumbu han ekonomi dunia dari $3,9 \%$ pada 2008 menjadi $2,2 \%$ pada tahun 2009. Eskposur pembiayaan LKS masih lebih diarahkan kepada aktivitas perekonomian domestik, sehingga belum memiliki tingkat integrasi yang tinggi dengan sistem keuangan global (Luqman, 2008).

Pengelolaan yang profesional berdasar kan prinsip syariah tentunya akan dapat membuat LKS memiliki kemampuan untuk terus tumbuh dan berkembang. Menurut Ludigdo dan Dhanias (2011) terdapat dua hal yang patut diperhatikan LKS. Pertama, LKS perlu mendorong umat agar lebih aktif berperan serta dalam pertumbuhan dan perkembangan ekonomi demi kemajuan umat. Kedua, LKS juga harus perperan lebih giat dalam komitmen sosial yang memiliki dampak kepada kehidupan yang lebih baik bagi manusia.

Murabahah dari sisi historis menurut Marwal (2010) adalah sistem jual-beli yang dijiplak dari negara Persia (salah satu negara adidaya disaat itu) oleh masyarakat Arab Islam dalam aktivitas bisnis mereka pada abad pertama hijriah. Sementara menurut Abdurrahman (2012) munculnya murabahah sebagai bagian dari produk LKS digagas oleh Dr. Sami Hamud dalam disertasi doktoralnya tahun 1976 dengan judul Tathwîr al-A'mâl al-Mashrifiyah bimâ Yattafiqu ma'a asy-Syarî'ah al-Islâmiyah, yang kemudian disebut murâbahah li al-âmir bi asy-syirấ. Namun dalam praktiknya hanya disebut murabahah saja. Faktanya murabahah tersebut berbeda dengan murabahah yang dijelaskan para fukaha yang memaknai murabahah dari asal kata al-Murabahahyang diambil dari bahasa Arab ar-ribhu yang berarti kelebihan dan tambahan (keuntungan), adalah jual beli dengan modal ditambah keuntungan yang diketahui. Murabahah yang digagas Hamud tersebut selanjutnya disebut sebagai murabahah kontemporer.

Dewan Syariah Nasional (DSN) Majelis Ulama Indonensia (MUI) melalui Keputusan DSN MUI No. 04/DSN-MUI/IV/2000 tentang murabahah dijadikan sebagai dasar dibolehkannya murabahah menjadi produk LKS. Untuk mendukung transaksi murabahah pada LKS, DSAS pun mengeluarkan standar akuntansi untuk murabahah yang 
diatur dalam PSAK No. 102 tentang Akuntansi Murabahah. Selanjutnya perlakuan akuntansi untuk praktik murabahah mengacu pada PSAK tersebut.

Perkembangan murabahah yang pesat menimbulkan dua pertanyaan: Apakah apli kasinya saat ini alami ataukah dipaksakan? Maksud aplikasi alami disini bahwa murabahah diposisikan sebagai sifat asalnya dan dipraktikkan secara benar. Dan jika dipaksakan, hal tersebut menunjukkan bahwa transaksi murabahah diimplementasikan tidak sebagaimana mestinya. Ada beberapa hal yang menjadikan praktik murabahah menjadi kurang syariah seperti yang disampaikan Kusmiyati (2007), hal-hal yang dinilai belum memenuhi persyaratan akad murabahah terdiri dari: pertama, murabahah digunakan untuk tambahan modal; kedua, pembelian barang murabahah, dilakukan dengan cara mewakilkan kepada anggotanya.

Ammar (2012)berpendapat bahwa implementasi murabahah pada LKS dilakukan dengan berbagai alasan: Pertama, karena kepercayaan dan kejujuran yang belum bisa dilakukan. Kedua, adalah alasan menyelamatkan dana umat agar aman. Sementara menurut Usmani (2003) alasan LKS menggunakan murabahah adalah: pertama, murabahah adalah suatu mekanisme investasi jangka pendek, dan dibandingkan dengan profit and loss sharing cukup memudahkan; kedua, mark-up dalam murabahah dapat ditetapkan sedemikian rupa sehingga memastikan bahwa lembaga keuangan dapat memperoleh keuntungan yang sebanding dengan keuntungan lembaga keuangan berbasis bunga yang menjadi saingan lembaga keuangan syariah; ketiga, murabahah menjauhkan dari ketidakpastian yang ada pada pendapatan bisnis-bisnis dengan sistem profit and loss sharing; keempat, murabahah tidak memungkinkan lembaga keuangan syariah untuk mencampuri manajemen bisnis, karena bukanlah mitra si nasabah, sebab hubungan mereka dalam murabahah adalah hubungan hutang-piutang dagang.
Al-Qur'an, bagaimanapun juga tidak pernah secara langsung membicarakan tentang murabahah, meski di sana ada sejumlah acuan tentang jual beli, laba, rugi, dan perdagangan. Demikian pula dalam hadist, tampaknya tidak ada hadist yang memiliki rujukan langsung kepada murabahah (Rahmawaty, 2007). Marwal (2010) juga menyampaikan bahwa seiring perkembangannya, murabahah akhirnya menjadi sistem jual beli yang dilegitimasi oleh para ulama klasik, bahkan keabsahannya merujuk kepada konstitusi ulama (ijma'), Imam Al-Kasani (dari ulama Hanafi) menjelaskan bahwa sepanjang sejarah semenjak dipraktikan sistem murabahah dari generasi ke generasi tidak ada segelintir komunitas muslim dan ulama yang mengingkari akan keabsaha sistem jualbeli murabahah. Hal itu dapat dijadikan rujukan sebagai bentuk ijma'.Di samping itu ada banyak alasan sistem jual beli murabahah ini diterima oleh banyak kalangan.Syarat utama yang harus diperhatikan pihak perbankan dalam menggunakan produk murabahah adalah bahwa prinsip-prinsip syariah untuk murabahah harus tetap dijaga (Febrianty, 2009).

Menurut Tuasikal (2012) pada prinsipnya, dalam proses murabahah kerelaan kedua belah pihak merupakan unsur yang penting. Prinsip dasar pembiayaan murabahah dijelaskan sebagai berikut: pertama, pembeli harus memiliki pengetahuan tentang biaya-biaya terkait dan harga pokok barang dan batas mark-up harus ditetapkan dalam bentuk persentase dari total harga plus biaya-biayanya; kedua, apa yang dijual adalah barang atau komoditas dan dibayar dengan uang; ketiga, apa yang diperjualbelikan harus ada dan dimiliki oleh penjual, dan penjual harus mampu menyerahkan barang itu kepada pembeli; keempat, ada akad jual beli (Muhammad, 2008). Yaya, et.al (2009:180) menyatakan bahwa dalam transaksi murabahah rukun yang harus dipenuhi meliputi transaktor, yaitu adanya pembeli (nasabah) dan penjual (bank syariah), objek akad murabahah yang di dalamnya terkandung barang dan harga, serta ijab 
dan kabul berupa pernyataan kehendak masing-masing pihak baik dalam bentuk ucapan maupun perbuatan.

Beberapa prinsip murabahah tersebut mengindikasikan adanya pemaknaan murabahah yang beragam, meskipun sebenarnya inti dari makna murabahah adalah sama. Perubahan makna terjadi ketika murabahah masuk dalam LKS, yaitu dari jual beli menjadi pembiyaan (Ernawati dan Ludigdo, 2012). Nelwan (2010) menunjukkan bahwa terdapat perbedaan pemaknaan antara pihak bank syariah yang menganggap murabahah adalah jasa pembiayaan atau financing dengan Ditjen Pajak yang menganggap murabahah merupakan transaksi jual-beli antara bank dengan nasabah, yang adalah obyek PPN, dengan hasil penelitiannya bahwa murabahah dimaknai sebagai bentuk jual beli menurut hukum Islam. Karena itu transaksi murabahah masuk menjadi obyek yang dikenakan PPN. Namun dalam praktiknya terjadi perubahan oleh berbagai pihak, sehingga murabahah tampak semata-mata hanya perjanjian pembiayaan. Pengenaan PPN adalah pada nilai tambahnya saja, dan method tax credit membuat tidak menimbulkan pajak berganda (non kumulasi).

Adanya perubahan dan keragaman pemaknaan murabahah dari makna awal kemudian masuk menjadi produk LKS, menjadi motivasi yang mendorong dilakukannya penelitian ini. Dengan demikian permasalahan yang ingin dijawab dalam penelitian ini adalah bagaimanakah pemaknaan terhadap murabahah oleh praktisi pembiayaan murabahah pada BMT dan ulama? Berdasarkan permasalahan yang ada, maka penelitian ini bertujuan untuk menemukan berbagai makna murabahah dari praktisi pembiayaan murabahah (manajemen dan nasabah) pada BMT dan ulama.

Hasil penelitian ini diharapkan dapat memberikan kontribusi baik secara teoretis maupun secara praktis. Kontribusi teoretis dalam penelitian ini adalah pemaknaan murabahah yang terkonstruk dari praksis, yaitu pertautan antara teori dan praktik.
Kontribusi teoretis kedua bagi kalangan akademisi maupun bagi peneliti adalah pemahaman bahwa pemaknaan murabahah sangat terkait dengan latar belakang historis dan kultur informan.

Secara praktis penelitian ini diharapkan dapat memberikan gambaran pentingnya pemahaman murabahah bagi SDM BMT dalam rangka mencapai murabahah yang lebih syariah. Tingkat pemahaman sangat dipengaruhi oleh latar belakang SDM, oleh karena itu dapat menjadi pertimbangan dalam proses rekruitmen. Kontribusi praktis kedua diharapkan berguna bagi masya rakat pengguna jasa lembaga keuangan syariah. Penelitian ini diharapkan dapat dijadikan sebagai pembelajaran bagi masyarakat ketika akan melakukan transaksi murabahah dengan LKS. Kontribusi praktis ketiga diharapkan hasil penelitian ini bermanfaat bagi DSN MUI dan DPS, terutama dapat dijadikan sebagai masukan dalam mengevaluasi praktik murabahahLKS.

\section{METODE PENELITIAN}

Suyanto dan Sutinah (2005: 167) menyatakan bahwa penelitian kualitatif menghasilkan data deskriptif mengenai kata-kata lisan maupun tertulis, dan tingkah laku yang diamati dari orang-orang yang diteliti. Ludigdo (2007:67) menyatakan bahwa paradigma interpretif yang lebih bersifat status quo, menekankan bahwa penelitian pada dasarnya dilakukan untuk memahami realitas dunia apa adanya. Paradigma interpetif merupakan kontribusi penting dari tradisi idealis para pemikir Jerman, sebut saja diantaranya Kant, Hegel, Dilthey, Weber, Husserl, Heidegger, Gadamer, Habermas dan Schutz (Djamhuri, 2011).

Penelitian ini merupakan penelitian dengan pendekatan kualitatif dengan menggunakan alat analisis hermeneutikaintensionalisme. Hermeneutika menurut Setiawan (2011) menitikberatkan pada inter pretasi dan pemahaman produk pemikiran manusia tentang dunia sosial dan budaya. Melalui wawancara dan teks yang menjadi acuan dalam penelitian ini, peneliti ingin 
berupaya menafsirkan maksud yang terkandung dalam setiap ucapan, ekspresi serta bahasa yang digunakan oleh pemberi informasi. Penafsiran ini pada akhirnya akan memberi sebuah pemahaman.

Kamayanti (2008) menyatakan bahwa hermeneutik atau hermeneutics diambil dari kata Hermes. Hermes adalah dewa dalam mitologi Yunani yaitu anak dari Dewa Zeus, yang bertugas sebagai utusan para dewa untuk menjelaskan pesan-pesan mereka. Awalnya hermeneutik digunakan untuk menentukan makna kesusasteraan Yunani, dengan pemikiran bahwa dalam perkataan manusia ada inspirasi Tuhan. Sehingga dapat dikatakan bahwa hermeneutik adalah refleksi pandangan hidup. Lebih lanjut Kamayanti (2008) menyatakan bahwa pada tataran ini hermeneutik merupakan pemaknaan mitologi, khususnya mitologi Yunani.

Kristen memerlukan hermeneutik untuk mencari nilai kebenaran Bible (Groundin, 2009: 46). Hal ini menurut Kamayanti (2008) disebabkan karenamereka memiliki masalah dengan teks-teks yang ada pada kitab sucinya. Mereka mempertanyakan apakah Bible adalah kalam Tuhan atau perkataan manusia. Maka diperlukan metode interpretasi dan hermeneutika untuk dapat memberi jawaban. Inilah perubahan fase hermeneutik dari fase mitologi ke fase teologi. Dalam hal ini Abdurrahman (2012) juga menyatakan bahwa asalnya, istilah Hermeneutika digunakan dalam bidang studi yang berkaitan dengan pengembangan metode dan aturan yang dapat memandu penafsiran kitab Injil. Selama tahuntahun pertama abad ke sembilan belas, Hermeneutika menjadi Hermeneutika Umum oleh filsuf dan teolog Protestan, Friedrich Schleiermacher. Schleiermacher telah berhasil menyulap Hermeneutika menjadi bidang kajian kefilsafatan, dengan mengangkatnya dari kajian yang secara spesifik hanya membahas bidang yang berkaitan dengan agama menjadi kajian yang mempunyai perhatian lebih tinggi terhadap filsafat umum tentang bahasa dan upaya pemahamannya.
Hermeneutika intensionalisme atau disebut juga hermeneutika romantisis, menurut Maulidin (2003:10) diusung oleh Friedrich Ernst Daniel Schleiermacher yang lahir 21 Nopember 1768 di Breslau Jerman. Schleiermacher hadir sebagai sosok pemikir yang memiliki suatu keyakinan kuat akan kekuasaan nalar manusia dan pelacakan yang paten untuk menyingkap kebenaran dalam setiap bidang. Schleiermacher mengidentifikasi interpretasi dengan kategori pemahamandan mendefinisi pemahaman sebagai pemahaman maksud pembicara dari sudut pandang arah semula dari situasi asli pada wacana (Recoeur, 2012: 58). Hermeneutika sebagaimana disampaikan Groundin (2007:17) secara tradisional dipahami sebagai teori interpretasi (hermeneu ein). Hermeneutika memiliki ciri khas orientasi pada historis.

Pendapat Schleiermacher yang dikutip Ricoeur (2012: 58) menyatakan bahwa untuk mencapai pemaknaan digunakan empati psikologis yaitu peneliti harus masuk ke dalam isi teks sampai mengalami kembali pengalaman-pengalaman pengarangnya.

Maulidin (2003:12) menyatakan, bahwa untuk sampai kepada kemampuan penafsiran seperti yang diangankan Schleier macher, seorang penafsir atau pembaca harus mampu memadukan aspek praktis dan teoretis dalam kerja-kerja hermeneutisnya. Metodologi gandanya ini merefleksi dua lapisan hermeneutika yang berbeda. Pertama, merupakan seperangkat alat filosofis dan eksegetis yang disebutnya sebagai rekonstruksi gramatikal, historis, dan komparatif, yang tidak lain adalah kerja hermeneutika pada lapisan praksis.

Sementara menurut Purnamasari dan Triyuwono (2010), upaya mencari makna memang selalu diikuti oleh upaya penafsiran yang memiliki tujuan untuk mendapat pemahaman. Secara ringkas, model kerja hermeneutika Schleiermacher meliputi dua hal. Pertama, pemahaman teks dilakukan melalui penguasaan terhadap aturan-aturan sintaksis bahasa pengarang, sehingga penggunaan pendekatan linguistikoleh penafsir 
menjadi suatu keharusan. Kedua, penangka pan muatan emosional dan batiniah pengarang secara intuitif dengan menempat kan diri penafsir ke dalam dunia batin pengarang teks. Langkah ini diperlukan untuk memandu langkah pertama agar panafsiran tidak melenceng jauh dari makna yang dikehendaki pengarang teks (Sari, 2010).

Dalam metode tafsir hermeneutika, untuk mengetahui makna sebuah ungkapan, kita harus menempatkannya ke dalam konteks yang lebih luas. Untuk memahami konteks yang lebih luas itu sebaliknya harus dipahami dahulu ungkapan-ungkapan khusus yang menyusunnya. Artinya, secara umum dapat dikatakan bahwa untuk memahami bagian-bagian kita perlu memiliki pemahaman tentang totalitas, dan totalitas dipahami melalui pemahaman atas bagianbagiannya. Struktur melingkar penafsiran ini disebut Hermeneutic Circle (Kamayanti, 2008).

Lingkaran hermeneutis ini adalah suatu problem besar. Jika interpretasi itu sendiri berdasarkan suatu interpretasi juga, maka lingkaran interpretasi tidak dapat dielakkan. Akibatnya pemahaman sesorang akan teks-teks dan kasus-kasus sejarah tidak akan pernah sampai, karena apabila seseorang dapat memahami konteksnya, maka konteks sejarah adalah interpretasi juga.

Dalam penelitian kualitatif, proses analisis tidak harus dilakukan menunggu selesainya proses pengumpulan data (Ludigdo, 2007:108). Maka, secara sistematis, proses analisis data ini akan dilakukan melalui tiga langkah. Pertama, peneliti akan mereduksi data. Kedua, peneliti akan melakukan analisis hermeneutika dengan cara menafsirkan teks, bahasa, ekspresi para informan beserta konteks kultur dan historisnya, menjadi sebuah kesatuan dan dapat menghasilkan makna.

Ketiga, peneliti akan menarik simpulan penelitian. Kesimpulan ini merupakan interpretasi dari hasil analisis yang di- lakukan pada langkah kedua. Untuk lebih mudahnya pemaknaan murabahah dapat dilihat pada gambar 1.

Dari gambar 1, dapat dilihat langkah hermeneutikaintensionalisme. "Teks", yang dalam konteks penelitian ini, diproksikan dengan informasi dari informan. Penafsir harus melihat dan mendalami konteks historis maupun kultural dalam "teks". Kultur atau budaya disini sering kali bersumber dari budaya suatu bangsa dan agama, namun umumnya juga budaya sangat dipengaruhi oleh nilai yang dianut organisasi serta dipengaruhi pula oleh perilaku pemimpinnya (Sopiah, 2008). Pada penelitian ini konteks kultur dan historis informan terdiri atas dua sudut pandang, pertama, dari sudut pandang praktisi BMT dan kedua dari sudut pandang ulama.

\section{Situs dan Informan}

Situs pada penelitian ini adalah BMT di Kab. Malang. Pemilihan pada situs ini berdasarkan hasil survey pra penelitian, bahwaterdapat praktik murabahah yang di sinyalir masih kurang syariah. Dalam penelitian kualitatif, kehadiran informan menjadi sangat penting. Tanpa ada informan yang memiliki informasi-informasi mendalam yang dapat digali oleh peneliti, maka sebuah penelitian kualitatif juga tidak dapat terjadi. Informan dalam penelitian ini ada sembilan orang, empat orang dari ulama,dua orang dari manajemen BMT,dan tiga orang dari nasabah BMT.

Dengan pertimbangan kondisi, maka dipilihnya sembilan informan tersebut di rasa mampu untuk memberi informasi mendalam dan sesuai dengan konteks penelitian. Informan yang pertama dari sudut pandang ulama adalah AZ. Selain Dosen beliau juga aktif di beberapa lembaga dakwah Islam. AZ juga banyak membuat tulisan tentang muamalah syariah. Informan kedua dari ulama adalah MS.

Beliau pemilik Pondok Pesantren yang sering memberi tauziah tentang muamalah tidak hanya di masyarakat sekitar pondok, 


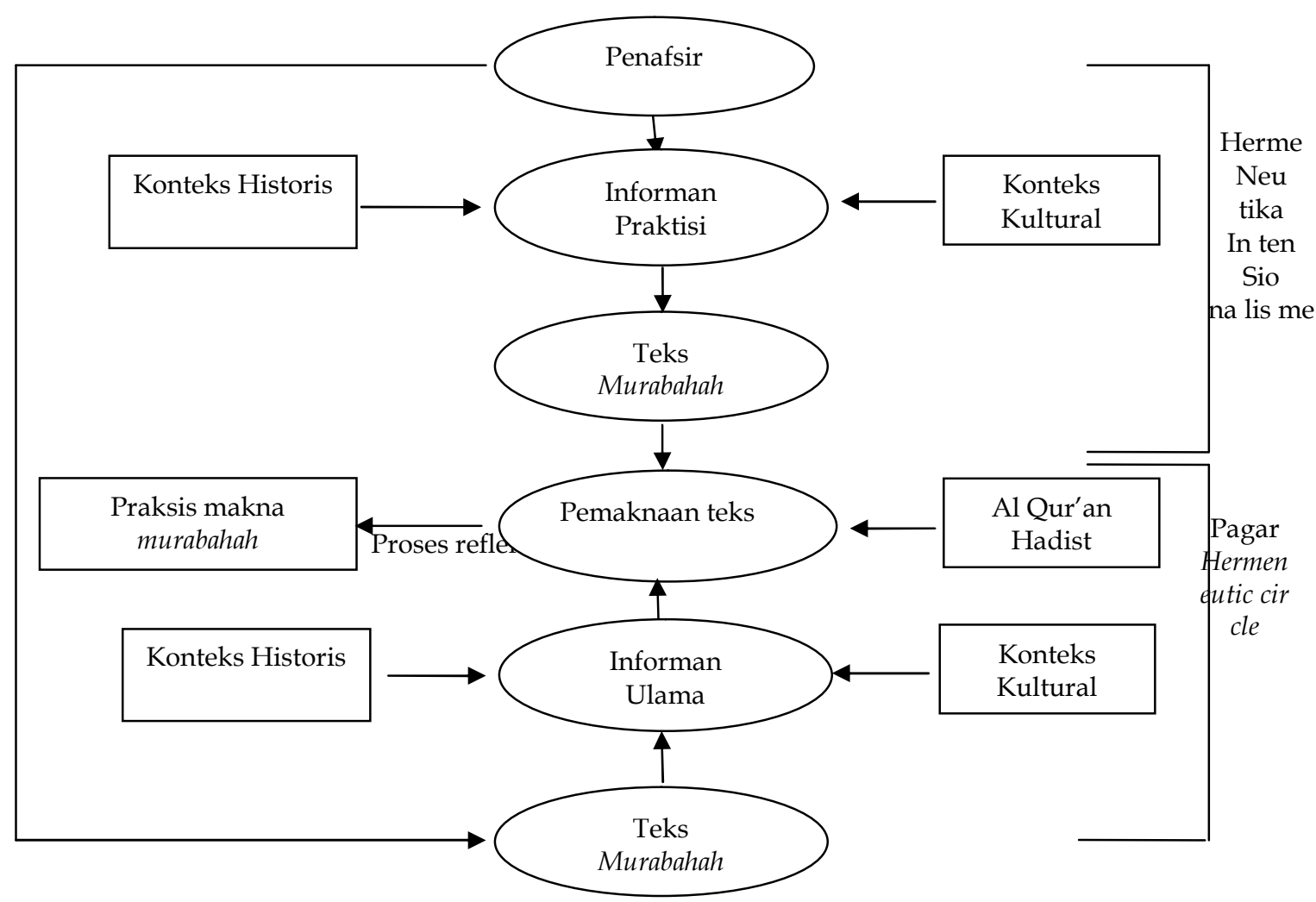

Gambar 1.

Sumber: Maulidin (2003:7) dimodifikasi

Proses Hermeneutika Intensionalisme Terarah

tetapi juga dibeberapa perguruan tinggi baik negeri maupun swasta. Informan ke tiga adalah ZN. Putra dari MS ini selain aktif berdakwah, juga memahami bagaimana bermualah secara syariah. Pemahaman tentang bermuamalah secara syariah pada LKS diperoleh dari pondok pesantren tempatnya menimba pengetahuan agama yang juga memiliki LKS. Informan keempat, adalah RZ. Beliau adalah salah seorang ustad, kepala sekolah SMA Islam di bawah naungan pondok, ketua pengurus pondok, dan beliau juga sarjana akuntansi.

Sementara dari sudut pandang mana jemen BMT, informan pada penelitian ini adalah RF, pemilik ide pendirian BMT pada Pondok. Beliau juga salah satu pendiri dari organisasi Al Kamil di Jawa Timur. Informan ke dua adalah WA. Beliau memiliki latar belakang pendi- dikan pondok pesantren, dan menempuh S1 jurusan pendidikan agama Islam, yang kemudian mendapat kepercayaan untuk mengembang kan BMT. Dari sudut pandang nasabah murabahah BMT, Informan pertama adalah ZM, beliau adalah salah satu staf di koppontren dan juga mahasiswa semester akhir jurusan akuntansi pada PTS di Malang, dengan demikian kehidupan pondok tidak asing baginya. Informan kedua adalah IA. Beliau merupakan pemilik bimbingan belajar untuk anak SD dan juga seorang ibu dari 2 orang putri. Meskipun tidak pernah merasakan kehidupan pondok dan tidak pernah menempuh pendidikan di madrasah, tapi beliau lebih suka bekerja sama dengan BMT. Informan ketiga adalah SP. Seorang tukang bangunan yang pernah mondok ini juga berakad dengan BMT. 


\section{MENELISIK MURABAHAH MURNI SYARIAH BAGI LEMBAGA KEUANGAN SYARIAH}

Lathif (2012) menjelaskan bahwa menurut istilah, para ulama fiqih mendefinisi murabahah sebagai berikut: pertama menurut Burhanuddin al Marghinani dari madzhab Hanafi, murabahah adalah memindahkan sesuatu (harta) yang dimiliki dari hasil akad (jual beli) yang pertama dengan harga pembelian (al tsaman al awwal) pada akad yang pertama disertai dengan pengambilan tambahan keuntungan. Kedua menurut Ibnu Rusdy dari madzab Maliki mendefinisi murabahah adalah jual beli yang terjadi apabila penjual menyebutkan kepada pembeli harga awal pembelian (al tsaman al awwal) barang dan mensyaratkan adanya keuntungan baik dalam bentuk dinar ataupun dirham. Ketiga menurut Imama Mawardi dari madzhab Syafii memberi makna murabahah dalam bentuk ilustrasi sebagai berikut: jual beli murabahah adalah apabila seorang berkata "Aku jual baju ini kepadamu secara murabahah, dari harga beli sebesar seratus dirham, saya mengambil keuntungan pada setiap sepuluh dirham sebesar satu dirham". Keempat menurut Ibnu Qudamah al Maqdisi dari madzab Hambali, memaknai murabahah dengan singkat dan padat yaitu jual beli dengan harga modal ditambah keuntungan tertentu.

Beberapa pemaknaan terhadap murabahah tersebut merupakan penjelasan tentang murabahah dalam literatur klasik, di mana barang obyek murabahah tersedia dan dimiliki penjual pada waktu negosiasi. Kemudian ia menjual barang tersebut kepada pembeli dengan menjelaskan harga beli dan keuntungan yang akan diperoleh. Karena itu dapat dikatakan praktik tersebut adalah transaksi jual beli biasa. Kelebihannya terletak pada pengetahuan pembeli tentang harga beliawal sehingga menuntut kejujuran dari penjual dalam menjelaskan harga awal yang sebenarnya.

Jika lebih dicermati lagi sebenarnya meskipun merupakan hasil ijtihad, ke- beradaan murabahah sesuai makna aslinya merupakan bagian dari dakwah serta ajakan untuk semua manusia khususnya umat Islam agar lebih memperhatikan kejujuran. Akan lebih baik lagi jika murabahah dipraktikkan dalam transaksi jual beli secara umum. Selanjutnya murabahah ini dijadikan sebagai bagian dari produk lembaga keuangan syariah.

Telah ada konsensus yang kuat di antara para ulama bahwa operasi lembaga keuangan syariah harus berdasarkan sistem bebas bunga. Gharar dapat didefinisikan sebagai suatu situasi di mana para pihak yang berkontrak tidak menguasai informasi tentang subyek kontrak mereka. Oleh karena itu tipe-tipe future contracts di mana satu pihak ternyata tidak menunjukkan penguasaan terhadap komoditi yang ditransaksikan, apalagi dengan tanpa penyerahan barang (non delivery trading contract), adalah tidak sah. Namun demikian, pihak yang dikenal sebagai produsen suatu barang boleh melakukan transaksi pesanan melalui bay'al salam yaitu transaksi spot dengan penyerahan barang kemudian. Dalam kerangka itulah Dewan Syariah berfungsi untuk memberi advis kepada lembaga keuangan syariah guna memastikan bahwa lembaga keuangan syariah dalam operasionalnya tidak terlibat dalam kontrak yang mengandung unsur-unsur yang tidak disetujui oleh Islam (Yulianti, 2007).

Lathif (2012) berpendapat bahwa dalam praktik murabahah pada lembaga keuangan syariah tidak ada keseragaman model. Terdapat banyak faktor yang melatarbelakangi hal tersebut. Beberapa tipe penerapan murabahah dalam praktik lembaga keuangan syariah kesemuanya dapat dibagi menjadi tiga kategori besar, yaitu: Murabahah tipe pertama, pada tipe ini praktik murabahah yang dijalankan konsisten terhadap figh muamalah, di mana lembaga keuangan membeli dahulu barang yang akan dibeli oleh nasabah setelah ada perjanjian sebelumnya. Setelah barang dibeli atas nama bank, barang tersebut kemudian dijual ke nasabah dengan harga perolehan 
ditambah margin keuntungan sesuai kesepakatan LKS dan nasabah. Pembelian dapat dilakukan secara tunai atau tangguh, baik berupa angsuran atau sekaligus pada waktu tertentu. Pada umumnya nasabah membayar secara tangguh.

Murabahah tipe kedua mirip dengan tipe pertama, tetapi terdapat perpindahan kepemilikan langsung dari supplier kepada nasabah, untuk pembayarannya dilakukan LKS langsung kepada penjual pertama/ supplier. Nasabah selaku pembeli akhir akan menerima barang setelah sebelumnya melakukan perjanjian murabahah dengan LKS. Pembelian oleh nasabah dapat dilakukan secara tunai atau tangguh baik berupa angsuran atau sekaligus pada waktu tertentu. Pada umumnya nasabah membayar secara tangguh. Transaksi ini lebih dekat dengan murabahah yang asli, tetapi rawan dengan masalah legal. Menurut Lathif (2012) dalam beberapa kasus ditemukan adanya klaim nasabah bahwa mereka tidak berhutang kepada bank, tetapi kepada pihak ketiga yang mengirimkan barang, meskipun nasabah sudah menandatangani perjanjian mura bahah dengan lembaga keuangan syariah. Perjanjian ini kurang memiliki kekuatan hukum karena tidak ada tanda bukti bahwa nasabah menerima uang dari bank sebagai bukti pinjaman atau hutang. Untuk menghindari kejadian seperti itu, maka ketika lembaga keuangan syariah dan nasabah telah menyetujui untuk melakukan transaksi murabahah, maka bank akan mentransfer untuk membayar barang ke rekening nasabah (numpang lewat) kemudian di debet dengan persetujuan nasabah untuk ditransfer ke rekening supplier. Dengan cara seperti ini maka ada bukti bahwa dana pernah di transfer ke rekening nasabah. Namun demikian, dari perspektif syariah model murabahah seperti ini tetap saja berpeluang melanggar ketentuan syariah jika pihak lembaga keuangan sebagai pembeli pertama tidak pernah menerima barang atas namanya, tetapi langsung atas nama nasabah. Karena dalam prinsip syariah akad jual beli murabahah harus dilakukan setelah barang secara prinsip menjadi miliki bank.

Murabahah tipe ketiga, merupakan mura bahahLKS.Lembaga keuangan syariah melakukan perjanjian murabahah dengan nasabah, pada saat yang sama LKS mewakilkan (akadwakalah) kepada nasabah untuk membeli sendiri barang yang dibutuhkan. Berikutnya dana tersebut di kredit ke rekening nasabah dan nasabah menandatangani tanda terima uang. Tanda terima uang ini menjadi dasar bagi pihak LKS untuk menghindari klaim bahwa nasabah tidak berhutang kepada lembaga keuangan syariah karena tidak menerima uang sebagai sarana pinjaman. Tipe ketiga ini menyalahi ketentuan syariah jika LKS mewakilkan kepada nasabah untuk membeli barang dari pihak ketiga, sementara akad jual beli murabahah telah dilakukan sebelum barang secara prinsip menjadi milik LKS.

\section{MURABAHAHMENURUT ULAMA}

\section{Konteks Kultur dan Historis Informan}

Murabahah yang murni syariah saat ini masih terus diupayakan. Meskipun sudah dijelaskan pada halaman sebelumnya tentang murabahah yang murni syariah secara teoretis adalah menurut DSN MUI. Namun demikian, pada penelitian kali ini peneliti ingin menggali makna murabahah dari sudut pandang ulamadi luar koridor MUI. Ada tiga ulama yang dijadikan informan. Pertama adalah AZ. Beliau adalah seorang dosen pada salah satu perguruan tinggi Islam di Jakarta. Sarjana Jurusan Peradilan Agama Fakultas Syariah ini juga menempuh strata dua jurusan Syariah pada tahun 2000.

Tahun 2008 AZ menempuh strata dua lagi untuk jurusan hukum ekonomi dan saat ini beliau sedang menempuh strata tiganya dengan jurusan syariah. Selain background pendidikan yang notabene adalah syariah, AZ juga merupakan sekretaris dari Himpunan Ilmuwan dan Sarjana Syariah Indonesia (HISSI). Beliau juga sebagai pengurus Komite Bidang Advokasi, Penelitian, dan Pengembangan Hukum Syariah Masyarakat 
Ekonomi Syariah (MES), Pengurus Departemen Hukum Muamalah Maliyah Ikatan Ahli Ekonomi Islam (IAEI) Pusat, Ketua 1 Ikatan Ahli Ekonomi Islam, Dewan Pengawas Syariah dibeberapa lembaga keuangan syariah di Jakarta.

Selain itu AZ juga menulis buku-buku figh muamalat, filsafat hukum Islam, serta menulis standarisasi kompetensi hakim pengadilan agama dalam menyelesaikan dispute di lembaga bisnis syariah. Masih segudang pengalaman, tulisan jurnal dan artikel beliau tentang syariah. Berdasarkan beberapa hal tersebut peneliti merasa AZ memenuhi persyaratan untuk dijadikan informan dari sudut pandang ulama. Penggalian data dari AZ dilakukan melalui $e$ mail.

Informan kedua adalah Putra dari Kyai pemilik Pondok Pesantren yaitu ZN. Alumnus Pondok Pesantren ini aktif mengikuti setiap kegiatan keagamaan di pondoknya dan juga di masyarakat sekitar. Sosok yang kritis dan tegas ini juga ustad yang mengajar di pondoknya juga masyarakat sekitar pondok. Selain ZN, MS ayah kandungnya juga aktif berdakwah di beberapa kota di Indonesia. MS sering diundang oleh beberapa perguruan tinggi untuk diminta berbagi ilmu agama. Keramahannya menjadikan siapa saja tidak segan untuk menimba ilmu dari beliau. Kyai yang humoris dan sederhana ini memiliki ribuan santri yang diasuh dalam pondok pesantrennya melalui Madrasah Diniahnya. Berdasarkan beberapa hal tersebut MS dan ZN layak untuk dijadikan informan. Informan keempat adalah RZ.

Profesi RZ adalah Kepala Sekolah SMA Islam di Malang. Beliau juga merupakan Ketua Pengurus Ponpes. Bapak yang pembawaannya kalem dan bersahaja ini sejak kecil sudah mengenal kehidupan pondok. Pendidikan pondok yang diperoleh disempurnakannya dengan pemahaman ten tang pengetahuan umum. Karena meskipun mondok, RZ juga menempuh pendidikan sampai sarjana. Kegiatan sehari-hari RZ selain aktif di sekolah dan di pondok juga berdakwah di daerah sekitar pondok dan daerah asalnya.

Keempat informan tersebut dinilai cukup memberi gambaran yang berbeda antara latar belakang kehidupan, tempat bekerja maupun pengalaman dalam dakwah mereka. Dengan perbedaan tempat tinggal, tuntutan kehidupan juga akan berbeda. Disadari ataupun tidak tuntutan kehidupan akan mengendalikan usaha manusia untuk pemenuhannya.Keempat informan dari ulama tersebut dirasa mampu untuk memberikan perbedaan pemaknaan.

\section{Pemaknaan Murabahah oleh Ulama Berdasarkan Hermeneutika \\ Intensionalisme}

Berdasarkan pengalaman yang dimiliki dan pemahaman yang dimiliki terhadap lembaga keuangan syariah baik secara teoritis maupun praktis khususnya untuk produk murabahah, berikut pendapat AZ dalam memaknai murabahah:

Murabahah adalah salah satu model jual beli amanah (transparan), di mana pihak pembeli mengetahui secara jelas berapa keuntungan (margin) yang diambil penjual, atau penjual (wajib) transparan dengan biaya modal pembelian obyek jual beli.

Pendapat di atas memberi pemahaman bahwa jual beli murabahah adalah jual beli amanah. Pemaknaan terhadap murabahah tersebut dapat peneliti kategorikan sebagai murabahahyang murni syariah sebagaimana pendapat DSN MUI dan para ulama klasik. Sementara praktik yang ada saat ini menurut AZ adalah sebagai berikut:

Praktik murabahah belum mencapai tingkat paling ideal (KW1), tetapi masih KW 3 karena kondisi obyektif lapangan yang belum memungkinkan atau karena masih mempertimbangkan efisiensi untuk optimali sasi laba.

Pendapat tersebut dapat di persepsikan bahwa AZ paham sekali bagaimana harusnya murabahah yang benar-benar syariah. Praktik murabahah pada lembaga keuangan syariah yang ada saat ini masih jauh dari murabahah yang ideal atau yang murni syariah. Kualitas nomor tiga (KW 3) dari 
praktik murabahah ini sama dengan apa yang beliau tulis bahwa tipe tiga praktik murabahah menyalahi ketentuan syariah jika bank mewakilkan kepada nasabah untuk membeli barang dari pihak ketiga, sementara akad jual beli murabahah telah dilakukan sebelum barang secara prinsip menjadi milik bank. Hal ini disebabkan antara lain karena kondisi laparangan yang belum memungkinkan untuk dilaksanakannya murabahah yang murni syariah, selain itu tujuan utama dari LKS yang masih pada optimalisasi laba.

Dengan analisis hermeneutikaintensionalisme, AZ yang berprofesi sebagai dosen sekaligus bagian dari Badan Pengawas Syariah bagi lembaga keuangan syariah dan segudang profesi lain terkait dengan bisnis syariah memaknai murabahah berdasarkan makna asalnya yaitu sebagai jual beli amanah. Namun secara praktis masih jauh dari makna asal.

Informan kedua dari sudut pandang ulama adalah MS. Pemilik dari pondok pesantren ini selain humoris juga menjunjung tinggi kesederhanaan dalam pola hidupnya. Pemilik Madrasah Diniyah berlantai lima ini sudah lama bergelut dengan hukum-hukum Islam dan mengajarkan ilmunya kepada anak dan santrinya. Berdasarkan hasil wawancara MS ternyata tidak mau berhubungan dengan bank. menurut- nya bank yang ada di Indonesia tidak ada yang lepas dari riba. Sebagaimana pendapat yang dikemukakannya:

Beberapa bank sekarang ini di negaranegara Islam paling banyak dikerjakan dengan jalan riba. Bahkan bank tidak didirikan kecuali dengan jalan riba. Makanya tidak boleh bekerja sama dengan bank yang berjalan dengan riba kecuali dalam keadaan terpaksa.

Ketika lembaga keuangan didirikan dengan jalan riba tentu segala sesuatu yang dikerjakan untuk kepentingan lembaga keuangan juga mengandung riba. Produkproduk yang dimiliki juga sarat riba. Oleh karena itu pendirian lembaga keuangan Islam dengan praktik yang murni syariah perlu dilakukan. Namun setelah didirikan bank Islam, tetapi praktik yang dilakukan tidak islami bagaimana, itulah yang menjadi pekerjaan rumah para ulama khususnya agar lebih aktif lagi memberikan pemahaman kepada masyarakat tentang bermuamalah yang lebihsyariah. Termasuk pada operasional lembaga keuangan syariah dan produk-produk yang dimiliki. Terhadap murabahah berikut pendapat MS:

Murabahah itu ya jual beli, syarat jual beli berarti barangnya harus kelihatan. Kalau tidak ada barang belum tentu orang pinjam uang untuk beli itu.

Secara praktik memang MS tidak memahami bagaimana murabahah pada lembaga keuangan syariah saat ini. Karena menurut beliau, salah satu budaya orang Madura adalah tidak suka bekerja sama dengan bank. Karena menurutnya hampir semua bank dijalankan dengan riba. Namun ketika merujuk ke hukum jual beli secara Islam beliau mensyaratkan barang yang diperjualbelikan harus ada. Pendapat ini sama dengan apa yang ditulis oleh Lathif (2012) yaitu yang disebut dengan murabahah tipe satu (KW 1) yaitu praktik murabahah yang dijalankan konsisten terhadap figh muamalah, di mana lembaga keuangan membeli dahulu barang yang akan dibeli oleh nasabah setelah ada perjanjian sebelumnya. Setelah barang dibeli atas nama bank, barang tersebut kemudian dijual ke nasabah dengan harga perolehan ditambah margin keuntungan sesuai kesepakatan LKS dan nasabah.

Informan ketiga pada penelitian ini adalah ZN. Putra dari MS ini sangat prihatin dengan kondisi perbankan syariah yang ada saat ini. Meskipun tidak bekerjasama dengan pihak lembaga keuangan syariah, ZN memahami bahwa praktik yang ada masih kurang syariah. Berikut pendapat yang disampaikan:

Akad apa saja kalau ada jalur manfaat dari salah satu pihak hukumnya haram. Kalau ada istilah narik manfaat ada perjanjian, menarik manfaat dari satu orang yang berakad dan disebutkan dalam akad, itu ndak boleh. Tapi ketika setelah berakad terus 
entah makan-makan dulu baru bicara tambahan ndak papa. Intinya akad tersebut harus ada jeda.

Pendapat tersebut sangat mungkin bisa dilakukan oleh lembaga keuangan syariah. Bahwa pengambilan keuntungan dari salah satu pihak dalam satu akad dan satu waktu hukumnya haram. Untuk itu perlu ada rentang waktu atau jeda yang pada akhirnya membolehkan akad tersebut dilakukan. Jeda yang dimaksud tidak harus makan-makan, namun bisa juga dengan aktivitas lain seperti keluar ruangan sebentar atau membicarakan yang lain dulu baru kembali ke akad. Satu hal yang menarik pada diri ZN adalah beliau menganjurkan kepekaan seseorang terhadap bahasa yang digunakan. Karena bahasa atau ucapan sangat berpengaruh terhadap sah tidaknya suatu akad. Ketika ditanya mengenai murabahah berikut pendapat beliau:

Murabahah itu la dlolalah wa la dhiroh nggak ada yang dirugikan dan ndak ada yang merugikan itu prinsip dari Rosul. Kita harus ridlo. Jadi praktik yang ada sekarang bukan murabahah.

Dengan demikian menurut pendapat beliau murabahah yang ada sekarang wajib di- rubah. Berikut pendapat ZN tentang hal tersebut: Menawi saget dirubah niku wajib dirubah (kalau bisa dirubah itu harus dirubah). InsyaAllah nasabah berani koq masuk ke bank syariah.

MS dan ZN merupakan ayah dan anak pemilik dan pengelola Ponpes ini memang enggan bekerja sama dengan bank. Namun demikian berdasarkan sudut pandang bahasa dan pemahaman yang diperoleh terkait murabahah, MS dengan konteks kultur dan konteks historisnya memberi makna pada murabahah sebagai jual beli. Meskipun telah menjadi produk LKS, ketika akad yang digunakan adalah jual beli, maka pihak LKS selaku penjual juga harus memiliki barang yang akan dijual kepada nasabah. Intinya bahwa syarat jual beli yang berlaku secara syariah berlaku juga bagi LKS. Sementara ZN dengan konteks kultur dan konteks historisnya dalam memberi makna terhadap murabahah lebih kepada sifat yang menyer- tainya sebagai akad jual beli yaitu tidak merugikan dan tidak dirugikan atau saling menguntungkan. Informan keempat adalah RZ.Berikut makna murabahah menurut beliau:

Secara bahasa murabahah berasal dari kata robahah kata dasarnya ro, ba, dan ha. Dalam bahasa Arab ribhun artinya keuntungan. Lha kalau kita alih bahasa kan secara sharafnyayaitu murabahah berarti mengikuti wazan fa ala yufa ilu mufa' alatan itu bisa mengandung arti saling. Sehingga robaha yurobihu mura bahatan artinya saling memberikan keuntungan.

Makna murabahah yang disampaikan RZ memiliki makna saling menguntungkan. Menurut RZ fiqh itu pilihan, ada takaran yang lebih ringan ada yang lebih berat. Ketika orang itu mau berhati-hati maka lebih baik mengikuti fiqih klasik. Lebih lanjut RZ berpendapat:

Kalau murabahah itu hasil ijtihad. Ijtihad itukan pendapat manusia,ketika nanti ada pendapat yangdianggap lebih relevan ya menggantikan pendapat sebelumnya. Karena pihak yang melakukan ijtihadkan bukan orang sembara ngan. Orang yang banyak pengetahu- annya.

Sementara untuk akad jual beli sendiri menurut RZ yang benar harus memenuhi syarat hukum jual beli, yaitu ada penjual, ada pembeli, ada barang, dan ada akad jual beli. Jika salah satu syarat tidak terpenuhi maka hukum jual beli tersebut batal. Hukum jual beli yang disampaikan RZ, ZN, dan MS, merujuk kepada hukum jual beli yang tertulis pada Al Qur'an Surat Al Baqarah ayat 275 yang artinya:"...Dan Allah telah menghalalkan jual beli dan mengharamkan riba....". Dan hadits Nabi: ditanya salah seorang sahabat mengenai pekerjaan (profesi) apa yang paling baik. Rasulullah menjawab: usaha tangan manusia itu sendiri dan setiap jual beli yang diberkati (HR al-Bazzar dan al-Hakim). Hadits tersebut menunjukkan bahwa jual beli dianjurkan dalam berusaha. Karena banyaknya ragam jual beli, maka setiap yang bertransaksi hendaknya memperhatikan rukun dan syarat sah dari masingmasing tipe jual beli. 


\section{PEMAKNAAN MURABAHAH OLEH MANAJEMEN BMT \\ Konteks Kultur dan Konteks historis}

Secara historis, RF sejak kecil sudah tinggal di pondok.Alumni STIE Koperasi ini juga merupakan pemrakarsa berdirinya BMT. Sebelum BMT berdiri, beliau adalah pendiri dari Alkamil yang beranggotakan orang-orang yang peduli dengan lembaga keuangan mikro syariah se Jawa Timur. Lepas dari Alkamil, RF dibantu oleh Bank Muamalat Indonesia mendirikan lembaga keuangan mikro syariah di bawah naungan Koppontren. Berikut pendapat RF:

Saya sendiri ndak ngerti bagaimana mendirikan bank. hanya karena semangat ingin mengetahui seperti apa sih perbankan syariah. Kalau kita tidak praktik langsung kita ndak akan paham. Kesalahan yang sebenarnya kita kan ndak tau. Kalau dulu ngaji figh tapi praktiknya ndak ngerti. Dan memang antara teori dan praktik masih jauh dari kebenaran. Makanya saya buat slogan di BMT "Usaha Menuju Syariah Murni". Karena kita belum bisa mengatakan syariah.

RF mempunyai seorang anak yang saat ini baru lulus sekolah dasar. Dengan bekal yang dimiliki, RF memiliki kekritisan yang cukup tinggi, apalagi terhadap hal-hal yang berhubungan dengan lembaga keuangan syariah. Karena itu RF menarik untuk dijadikan sebagai salah satu informan.

Informan kedua dari pihak manajemen BMT adalah WA. WA merupakan nara sumber yang penting dalam penelitian ini. Pendapat-pendapatnya menjadi informasi yang penting untuk disampaikan. Secara historis WAberpendidikan formal keagamaan, mulai Madrasah Ibtida'iyah (MI), Madrasah Tsanawiyah (MTs), Madrasah Aliyah (MA), dan pendidikan Agama Islam. Setelah menempuh pendidikan MAnya, WA memperdalam diniahnya.

\section{Pemaknaan Murabahah oleh Manajemen BMT berdasarkan Hermeneutika Intensionalisme}

Berbagai pemaknaan terhadap murabahah telah dilakukan banyak pihak. Baik itu yang termasuk dalam golongan ulama klasik, golongan ulama modern, pihakpihak yang terkait dengan praktik murabahah baik pihak manajemen LKS maupun masyarakat secara umum. Banyak hal yang menyebabkan terjadi perbedaan dalam memaknai murabahah oleh individu. Latar belakang si pemberi makna dan berbagai kepentingan yang diinginkan menjadikan praktik murabahah yang terjadi pada LKS masih jauh dari makna awal dibolehkannya murabahah sebagai salah satu dari produk perbankan.

Di BMT sendiri pihak manajemen dan stafnya sudah tidak asing lagi dengan istilah murabahah. Hal ini karena sampai dengan saat ini akad yang berani dilakukan pihak BMT dan nasabah hanya akadmurabahah. Beberapa faktor selain kemudahan administrasinya, dalam akadmurabahah kejelasan margin juga menjadi alasan mengapa harus murabahah yang dipraktikkan. Sebagai produk LKS, murabahah pada BMT praktiknya juga mengacu pada praktik murabahah pada perbankan syariah. Hal ini dikarenakan pada awal pendirian BMT, modal diperoleh melalui akadmudharabah dengan BMI. Untuk itu, sistem pembayaran kembali (hutang) yang harus diselesaikan BMT tiap bulannya adalah pokok pinjaman ditambah bagi hasil yang sudah ditetapkan di awal akad. Jadi ketetapan pembayaran bagi hasil yang flat (tiap bulan dengan jumlah yang tetap sampai akhir akad) menjadikan pihak BMT memilih murabahah sebagai produk yang dapat memberikan kepastian hasil.

Sementara RF menyatakan bahwa praktik murabahahpada lembaga keuangan syariah saat ini telah menyimpang dari makna sebenarnya, alasan pertama penyimpangan adalah masyarakat sendiri belum siap dengan sistem perbankan syariah yang benar-benar syariah; kedua karena sistem perolehan dana untuk transaksi murabahah yang masih mirip sistem konvensional sehingga masih terdapat kandungan riba di dalamnya. Karenanya perlahan tapi pasti perubahan akan dilakukan agar makna murabahah sesuai dengan makna asalnya 
yaitu jual beli sesuai dengan misi BMT sendiri yaitu menuju syariah murni. Berikut ini makna murabahah menurut Pak RF: Murabahah itu adalah suatu sistem akad pinjaman yang aslinya adalah ada obyek yang diperjual belikan dengan sistem pembayaran tangguh. Memang dalam persyaratan fiqih muamalah jual beli harus ada barang yang dijual, ada serah terima barang yang dijual baik itu serah terima tertulis formal atau penyerahan barang.

Pendapat di atas hampir sama dengan apa yang disampaikan WA berikut ini: Murabahah yang saya ketahui, kita membelikan barang nasabah kemudian kita jual kepada nasabah. Sistem jual beli nasabah dengan kita dengan cara cicilan, harusnya kontan.

Namun ketika murabahah menjadi bagian dari BMT berikut pendapat WA:

Murabahah dalam teori itu harus membelikan barang dulu, apa yang dibutuhkan nasabah baru kita jual ke nasabah, ya. Kalau jual belikan ada untung. Margin itu yang kita anggap sebagai untung jual beli. Jadi mereka istilahnya kita beri boleh membayar dengan cara angsuran. Tetapi praktiknya tidak bisa sepraktis di teori.

Alasan BMT menggunakan murabahah sebagai produknya adalah sebagaimana yang disampaikan RF berikut ini:

Menggunakan murabahah itu untuk menghindari regulasi pemerintah terhadap perbankan. Kalau koperasi kan ndak boleh kita menggerakkan masyarakat untuk pinjaman kecuali bank. untuk menyiasati itu sistem murabahah itu ndak masalah.

WA memiliki pendapat yang berbeda dalam hal ini, yaitu:

Kalau kita memilih murabahah karena kita merasa itu yang paling cocok dengan kondisi masyarat saat ini. Sebenarnya murabahah hanya solusi akad riba yang dipraktikkan. Sementara ini di perbankan konvensional dengan akad simpan pinjam dan itu masih terkena fluktuasi meskipun hukum yang ada makruh mubah, tapi juga ada haram. Masak dalam Islam ndak ada sih. Dan ternyata di Islam produknya lebih banyak dari pada yang konvensional kenapa kita ndak pake. Makanya kita perang, itu yang disebut hijrah.
Pendapat tersebut menyiratkan bahwa perang tidak selalu menggunakan senjata tajam. Perang melawan sesuatu yang tidak tampak (merubah pola pikir) justru menjadi PR bersama yang membutuhkan banyak perhatian dan tindakan. Istilah perang menunjukkan adanya semangat untuk terus berdakwah, menyuarakan bermuamalah dengan cara yang lebih syariah kepada masyarakat. Sebagai contoh yang dilakukan pihak BMT setiap ada orang baru diberi penjelasan bahwa sistem syariah itu seperti ini. Sementara Kata hijrah juga menyiratkan bahwa kita hendaknya segera menuju tempat yang lebih baik dan lebih di ridloi Allah.

Pada BMT, praktik murabahah yang dilakukan juga masih menggunakan akadwakalah. Ketika akadwakalah ini digunakan banyak orang-orang pondok khususnya ulama menyalahkan penggunaan akadwakalah tersebut seperti yang disampaikan WA:

Ketika terjadi transaksi murabahah ada akadwakalah yang banyak syaratnya walaupun syaratnya tidak detail. Dan orang yang diwakilkan syarat-syaratnya harus ada. Sementara di sini belum bisa memenuhi semua syarat. Karena tidak mudah menjadikan nasabah menjadi pihak yang di wakalah.

Akad yang digunakan BMT, pertama akadmurabahah yang kedua akadwakalah, dan dana yang akan digunakan untuk membeli barang tersebut diberikan setelah akadwakalah selesai dilakukan. Menurut WA lagi:

Bahwa sebenarnya BMT ingin menerapkan praktik murabahah yang langsung. Tapi belum siap. Kita cari solusi lain jika ada masalah, misalnya dengan kerja sama dengan pihak-pihak yang memiliki showroom untuk produk yang diperlukan BMT. Kalau jual beli syaratnya harus ada barang, makanya kita kerjasama dengan dealer, dan lain-lain. Kalau misalnya sistemnya sudah bisa murni berarti kita terlepas dari belenggu, jadi tidak wakalah-wakalah lagi. Karena pada prinsipnya BMT menggunakan murabahah sebagai produknya adalah demi mendapatkan untung di jalur yang benar. 
Secara implisit pernyataan tersebut menunjukkan bahwa apa yang dilakukan BMT sebetulnya merupakan salah satu bentuk ibadah kepada Tuhan yaitu mendapatkan untung di jalur yang benar secara syariah.

Pada BMT juga menerapkan "murabahah tanggung renteng". Menurut WA dengan cara tanggung renteng, praktik murabahah jadi lebih enak karena tidak perlu melakukan penagihan, jika ada yang tidak bayar. Artinya itu mempermudah BMT. Berikut pendapat WA tentang murabahah tanggung renteng: "Dengan cara tanggung renteng, kita jadi lebih enak karena tidak perlu melakukan penagihan, misalnya ada yang tidak bayar. Artinya itu mempermudah BMT karena kita ndak harus survey, nagihi, karena ada koordinatornya. Awalnya dia sendiri (koordinator) mengajukan, koq baik lalu membawa saudara-saudara nya sampai orang-orang yang dikenal".

Murabahah dalam pendapat di atas menunjukkan bahwa praktiknya dapat dilakukan sesuai kultur di masyarakat. Fenomena tersebut merupakan hal baru pada BMT. Dengan menggunakan "murabahah" tanggung renteng, akan memengaruhi pendapatan BMT. Manfaat lain dari "murabahah" tanggung renteng adalah terjalinnya silaturahim sesama anggota. Eratnya silatu rahim yang terjalin akan mempermudah upaya BMT untuk memberikan pemahaman kepada masyarakat pengguna jasanya. Dalam pernyataan WA tersebut terlihat bahwa BMT memberikan kemudahan kepada masyarakat sekitar untuk bekerjasama dengan BMT.

Bentuk lain dari upaya pendekatan diri (lembaga) kepada masyarakat, selain juga menguntungkan bagi pihak BMT. Dengan tanggung renteng, setidaknya akan semakin banyak masyarakat yang mengenal dan kemudian bermuamalah dengan BMT. Tang gung renteng juga menunjukkan kepanjangan tangan BMT bagi murabahah untuk masyarakat. Melalui koordinator yang ditunjuk dari golongan masyarakat itu sendiri menjadikan masyarakat tidak sungkan untuk bekerjasama dengan BMT.
Pendapat tentang murabahah tanggung renteng juga disampaikan oleh RF bahwa "Sejak ada tanggung renteng jadi semakin banyak masyarakat yang tahu murabahah dan paham bagaimana bermuamalah dengan kita dengan cara yang syariah". Pendapat RF tentang bahwa murabahah tang gung renteng merupakan wadah bagi BMT untuk berdakwah dan bersilaturahim de ngan masyarakat. Mendekatkan diri kepada nasabah melalui perwakilan dari golongan mereka lebih mudah diterima dari pada mungkin pihak BMT sendiri yang terjun untuk mencari nasabah. Karena sebagaimana bunyi pepatah tak kenal maka tak sayang, BMT dikenalkan dari golongan mereka sendiri agar mereka menyayangi dan rindu bermuamalah dengan syariah melalui BMT untuk kemudian benar-benar terbiasa dengan hal tersebut dan harapan selanjutnya adalah bahwa masyarakat bisa meninggalkan bermuamalah dengan cara konvensional.

Pendapat WA yang menyatakan bahwa "dalam praktik murabahah harus adil dan kemudian harus saling menguntungkan. Dalam murabahah itu kan utang piutang karena jual beli denga cara dicicil kan sosial juga". Terdapat beberapa kata yang sarat makna dari pendapat tersebut. Di mana praktik murabahah yang dilakukan pada BMT harus adil, saling menguntungkan, utang piutang, jual beli, cicilan, dan sosial. Kata adil menunjukkan bahwa murabahah yang dipraktikkan saling menguntungkan. Bahkan utang piutang dalam jual beli ber kala ini juga berkontribusi pada kepenti ngan sosial. Kepentingan sosial yang dimak sud bahwa pihak BMT mempermudah pola pembayaran secara berkala sesuai kesepakatan.

Murabahah jual beli cicilan atau hutang dilakukan dengan membelikan barang atas permintaan nasabah kemudian menjualnya kepada nasabah tersebut. Sistem jual beli antara nasabah dengan BMT dilakukan dengan cara cicilan, padahal seharusnya kontan. Sesuai ketentuan DSN MUI tentang Murabahah, bahwa modal dalam murabahah 
merupakan barang. Jadi nasabah membutuhkan barang, BMT selaku pemilik dana membelikan untuk kemudian pembayarannya dilakukan secara tangguh atau cicilan. Pendapat yang sama disampaikan oleh RF bahwa "Murabahah itu adalah suatu sistem akad pinjaman yang aslinya adalah ada obyek yang diperjual belikan dengan sistem pembayaran tangguh".

Murabahah sebagai hutang juga nampak pada pernyataan RF di atas melalui kalimat "sistem pembayaran tangguh". "Murabahah" ini menjadikan masyarakat penggunanya merasa lebih mudah mendapatkan barang yang dibutuhkan, khususnya bagi mereka yang kurang mampu. Karena dengan "murabahah" hutang, kewajiban mereka dapat diselesaikan sesuai dengan kemampuan melalui kesepakatan yang dibuat dengan BMT.

\section{PEMAKNAAN MURABAHAH OLEH NASABAH BMT}

\section{Konteks Kultur dan Konteks Historis}

Kultur dan historis dari nasabah BMT diperlukan dalam penelitian ini, yaitu untuk memahami bagaimana seseorang (nasabah) dengan budayanya memaknai murabahah. Informan pertama dalam penelitian ini adalah ZM. Secara kultur dan historis, meskipun tinggal di lingkungan yang kurang agamis, namun ZM dibesarkan oleh keluarga yang agamis dan sejak SMP sudah mengenal kehidupan pondok. Pengaruh kehidupan dipondok nampak dari perilaku, cara berpakaian dan cara bicaranya. Kultur tersebut sarat dengan nilai-nilai Islam yang tentunya selain beberapa hal tersebut juga berpengaruh pada pola pikir beliau termasuk dalam bermuamalah.Beliau bekerjasama dengan BMT guna mengembangkan usaha ayahnya.

Informan ke dua adalah IA. Salah satu nasabah yang berasal dari masyarakat umum di luar kehidupan pondok, tapi di lingkungan yang agamis ini menjalani kehidupannya dengan kesederhanaan, karena sebagai pengelola dari lembaga bimbingan belajar bagi anak SD beliau juga memiliki sebuah toko kecil sebagai penunjang kebutuhan keluarga. Tinggal di lingkungan yang agamis berpengaruh pada kesantunan bicaranya, berpakaian, mendidik anak, dan dalam bermuamalah. Secara historis AI yang memiliki dua putri masih berstatus mahasiswa pada PTS di Malang. Pribadi yang murah senyum ini juga memahami bahwa bunga pada bank konvensional itu adalah riba. Bekerja sama dengan BMT dilakukannya guna mengembangkan usaha meskipun disekitarnya juga banyak lembaga keuangan konvensional yang memiliki fasilitas lebih baik.

Informan ketiga adalah SP. Secara kultur dan historis, SP adalah seorang tukang bangunan yang pernah mondok. Dalam hal pendidikan SP hanya lulus SMP yang kemudian melanjutkan belajarnya di salah satu pondok di Malang namun tidak tuntas karena sesuatu dan lain hal. Bapak dari seorang putra dan suami dari seorang istri ini tinggal di lingkungan yang kurang agamis. Bapak yang ramah ini ternyata juga suka dengan seni tradisional gamelan.

Secara umum budaya masyarakat masih lekat dengan budaya yang ada pada lembaga keuangan konvensional. Kebiasaan yang sudah turun-temurun bekerjasama dengan lembaga keuangan konvensional ini lah yang menguatkan pemahaman mereka bahwa setiap datang ke lembaga keuangan meskipun itu LKS adalah untuk hutang uang, dan tidak ada istilah jual beli pada perbankan.

Hal ini dapat dimaklumi karena memang jarang ditemukan lembaga keuangan yang berperan ganda, yaitu sebagai lembaga pemberi jasa keuangan sekaligus sebagai lembaga jual beli barang. Budaya ini yang kemudian menjadi kebiasaan memaknai produk LKS sama dengan produk LK konvensional.

\section{Pemaknaan Murabahah oleh Nasabah BMT Berdasarkan} HermeneutikaIntensionalisme

Pemahaman terhadap produk yang digunakan sangat diperlukan oleh nasabah 
LKS. Penting untuk dipahami supaya dalam berakad benar secara syariah sehingga akad nya sah. Hasil pemaknaan yang diberikan nasabah dalam penelitian ini dapat digunakan untuk menilai seberapa paham nasabah tentang murabahah. Pendapat SP tentang makna murabahahadalah:

"Saya ndak paham apa itu murabahah, tahunya saya hutang uang. Waktu akad juga dibacakan tentang akad yang akan saya lakukan tapi saya ndak ngerti".

Pendapat tersebut dapat ditafsirkan bahwa SP belum memahami akad yang dilakukan dengan BMT. Padahal sebelum akad, pihak BMT sudah menjelaskan tentang apa itu murabahah. Syarat awal sebelum Akad ditandatangani, nasabah tetap diminta membacanya lebih dulu, namun karena malu bertanya, SP akhirnya tidak memahami akad tersebut. Lebih lanjut SP menyampaikan bahwa:

"Saya kesini (BMT) karena dapat informasi dari teman bahwa di lembaga ini lebih mudah mendapat dananya dengan jaminan yang saya punya."

Penafsiran dari pendapat tersebut bahwa kemudahan mendapat dana menjadi hal yang menarik bagi nasabah untuk melakukan akad dengan BMT. Meskipun SP sebenarnya belum memiliki pemahaman terkait akad tersebut. Pendapat yang sama juga disampaikan oleh informan ke dua, yaitu IA bahwa:

"Pernah sih mendengar tentang murabahah, tapi kok saya ndak ngerti artinya. Jadi kalau kesini ya karena butuh uang untuk mengembangkan usaha.Waktu akad juga dikasih tahu akad apa yang saya lakukan tapi lupa."

Pendapat tersebut dapat interpretasikan bahwa nasabah kurang begitu tertarik untuk memahami tentang akad yang dilakukan. Dapat dimungkinkan hal tersebut diakibatkan oleh penggunaan bahasa Arab pada produk BMT tersebut.Karena bagi mereka yang penting adalah mereka dapat segera mendapat dana yang dibutuhkan tanpa peduli dengan akad apa yang dilakukan. Pernyataan "kalau ke sini ya karena butuh uang" mengindikasikan adanya hutang piutang uang, bukan hutang piutang barang. IA lebih tertarik melakukan akadmurabahah dengan BMT sebagaimana pendapatnya berikut:

Saya tertarik ke BMT karena lebih mudah syaratnya, lebih murah biayanya dan pastinya lebih syariah, itu yang membuat hati tenang.

Berdasarkan pendapat tersebut kata "murah" dan "mudah" menjadi faktor penting mengapa informan tertarik melakukan akad murabahah dengan BMT. Meskipun minim pemahaman, namun IA lebih suka bekerja sama dengan BMT karena dirasa lebih syariah sehingga membuat hatinya menjadi lebih tenang.

Berbeda dengan SP dan IA, ZM memiliki pemahaman yang lebih baik tentang makna murabahah sebagaimana yang beliau sampaikan berikut:

Murabahah itu pembiayaan yang se-

benarnya jual beli untuk membantu sesama yang membutuhkan.

Murabahah pada pendapat tersebut sama memiliki makna yang sama dengan kondisi murabahah dalam praktik di LKS saat ini termasuk BMT. Bahwa murabahah adalah pembiayaan bagi sesama yang mem butuhkan. Kutipan kata tersebut selian bermakna hutang (pembiayaan) juga bermakna sosial (membantu sesama). ZM memilih untuk berakad secara syariah karena lebih aman secara syariah, meskipun jumlah akhirnya lebih besar dari pada bertransaksi dengan bank konvensional.

Hasil wawancara dengan nasabah juga diketahui bahwa nasabah BMT dengan menggunakan akadmurabahah, yang diterima bukan barang tetapi uang yang akan digunakan untuk membeli kebutuhan nasabah. Demi tetap terjaganya norma syariah untuk murabahah, maka untuk pembelian barangnya, BMT membuat akadwakalah kepada nasabah. Dana dengan akadmurabahah harusnya digunakan sesuai ketentuan DSN MUI No. 04/DSN-MUI/2000 tentang murabahah, bahwa dana digunakan untuk pembelian barang yang dibutuhkan nasabah dan halal. Idealnya tetap pihak BMT yang 
menyediakan barang dan menjualnya kepada nasabah.

Kehidupan dalam lingkungan yang ber beda akan berpengaruh terhadap budaya yang berbeda, selanjutnya berpengaruh terhadap perilaku yang berbeda pula. Dalam penelitian ini kehidupan dengan lingkungan yang berbeda memberi makna terhadap produk LKS yang sama yaitu murabahah. Terdapat perbedaan dan persamaan jawaban informan terhadap pertanyaan peneliti. Sebagaimana permasalahan yang disampaikan sebelumnya tentang bagaimana pemaknaan murabahah oleh praktisi pembiayaan murabahahBMT dari nasabah, informan pertama SP yang baru 1 tahun menggunakan akadmurabahah pada BMT ini masih belum memiliki pemahaman tentang sesuatu yang diakadkan. SP masih memiliki persepsi bahwa produk yang dimiliki BMT sama dengan produk-produk pada LK konvensional. Jadi SP datang ke BMT bukan karena membutuhkan barang sebagaimana seharusnya akadmurabahah, tetapi yang diinginkan adalah uang untuk kebutuhan yang lain. Dapat diambil simpulan bahwa murabahah yang dipahami SP adalah hutang uang.

IA informan kedua juga masih belum memahami tentang makna murabahah yang sudah diakadkan dengan BMT.Sebagaimana pendapat SP, yang ada dalam pikiran IA terhadap akad yang dilakukan dengan BMT adalah akad hutang atau pinjam uang. Dengan demikian "murabahah hutang" merupakan pemaknaan yang diberikan informan selaku nasabah terhadap murabahah. Hutang yang dimaksud adalah hutang piutang uang dan bukan hutang piutang barang dari jual beli.

Kebanyakan pada BMT model pembayaran yang dilakukan oleh nasabah adalah dengan cara mengangsur sampai batas waktu yang disepakati. Dan jika dalam masa akad terjadi wanprestasi dari nasabah maka, pihak BMT akan menganalisis lebih dulu penyebab wanprestasi baru kemudian membantu mencari solusi yang tepat bagi nasabah.
Sementara pernyataan ZM bahwa mura bahah adalah pembiayaan yang sebenarnya jual beli kredit, menunjukkan adanya pemahaman tentang makna murabahah, meskipun kurang lengkap. Tetapi yang menarik dari pernyataan ZM adalah kehadiran "murabahah sebenarnya untuk membantu sesama". Pendapat tersebut juga mendukung pendapat manajemen BMT bahwa sebetulnya tujuan penggunaan murabahah sebagai produk BMT tidak semata demi keuntungan materi saja, tetapi orientasi sosial juga ada. Jadi keberadaan murabahah sejatinya untuk membantu yang membutuhkan dengan cara yang lebih syariah.

\section{KONSEPTUALISASI HASIL PEMAKNA-} AN ULAMA DAN PRAKTISI PEMBIAYA AN MURABAHAH

\section{Makna MurabahahTemuan}

Pertanyaan penelitian ini adalah bagaimana pemaknaan murabahah oleh praktisi pembiayaan dan ulama. Kata kunci pada penelitian ini adalah pemaknaan murabahah. Pemaknaan dilakukan dengan melihat konteks kultur dan konteks historis informan. Sebelumnya pemaknaan murabahah telah dilakukan oleh manajemen dan nasabah BMTserta ulama, sampai pada akhirnya ditemukan sebuah makna praksis.

Berdasarkan dari tiga sudut pandang tersebut, secara singkat makna murabahah dapat dilihat pada gambar 2 .

\section{Praksis Makna Murabahah}

Berdasarkan makna murabahah kontekstual dan hasil pemaknaan dari ulama dan praktisi pembiayaan murabahah yaitu manajemen dan nasabah, serta melalui proses refleksi maka makna murabahah yang ditemukan dalam penelitian adalah jual beli, amanah, adil, pembayaran berkala, murah, mudah, saling menguntungkan, silaturahim/tanggungrenteng, dan sosial. Nyata sekali bahwa makna yang ditemukan sangat beragam.

Berdasarkan hasil pemaknaan yang telah dilakukan dapat diambil nilai-nilai yang terkandung di dalam makna temuan 
tersebut, yaitu amanah, adil, sosial, ikhlas. Beberapa nilai tersebut hendaknya menyertai praktik murabahah yang dilakukan, khususnya pada lembaga keuangan syariah. Beberapa unsur tersebut menunjukkan bahwa murabahah secara praktis ternyata lebih humanis. Triyuwono (2006:320) memberi suatu pengertian bahwa humanis bersifat manusiawi, sesuai dengan fitrah manusia, dan dapat dipraktikkan sesuai dengan kapasitas yang dimiliki dan sesuai dengan budaya yang berlaku dimasyarakat. Dengan demikian murabahah humanis dibangun berdasarkan budaya manusia itu sendiri yang mengandung nilai adil, ikhlas, sosial, dan amanah (AISA).

Meskipun demikian tetap diperlukan pagar agar praktik yang ada tidak lepas dari nilai-nilai syariah. Harapannya makna yang peneliti temukan tidak menyesatkan bagi pembaca.

Pagar tersebut dapat digunakan untuk menemukan makna murabahah original yang lebih syariah. Selain mengembalikan makna murabahah ke makna asal, praktik yang ada dapat menerapkan murabahah humanis yang memiliki nilai amanah, adil, sosial, dan ikhlas. Berikut peneliti sampaikan alur makna murabahah menuju makna original yang lebih syariah berdasarkan teori dan praktis pada gambar 3.

Berdasarkan tahapan makna murabahah tersebut, tahap satu adalah makna murabahah yang diberikan oleh nasabah BMT. Tahap dua, merupakan makna murabahah yang diberikan oleh manajemen BMT. Tahap tiga adalah makna murabahah menurut ulama. Tahap empat adalah makna murabahah yang diberikan oleh DSN MUI. Dan tahap lima merupakan makna murabahah original hasil memadukan maknamakna yang ada pada tahap satu sampai empat. Murabahah original merupakan puncak dari makna murabahah berdasarkan teori dan praktik.

Makna murabahah yang peneliti padukan merupakan makna murabahah temuan penelitian. Makna murabahah temuan bisa jadi justru lebih syariah dan lebih original dari pada maknamurabahah yang diakui secara teori saat ini yaitu menurut DSN MUI. Tapi berdasarkan penelitian ini, makna murabahah yang original masih sebatas itu. Makna murabahah original lebih bersifat humanis. Selain itu juga lebih memperhatikan kepedulian sosial dari pada hanya sekedar jual beli yang menguntungkan. Mungkin sepintas nampak makna temuan lebih rumit. Namun demikian, sebuah makna sangat dipengaruhi oleh budaya yang berlaku serta latar belakang individu dan masyarakat yang ada. Dengan demikian perbedaan informan dan latar belakangnya, lokasi penelitian, daerah, dan bangsa akan memberikan pemaknaan terhadap teks murabahah yang ada juga berbeda.

\section{Simpulan}

Setelah melalui proses yang panjang, penelitian yang dilakukan untuk pemaknaan murabahah oleh manajemen dan nasabah BMT serta ulama, dapat diketahui bahwa makna murabahah temuan memiliki definisi yang lebih beragam. Hermeneutikaintensionalisme yang digunakan dalam penelitian ini untuk memahami bagaimana informan memaknai murabahahdengan berdasarkan pada latar belakang kultur dan historisnya.

Ternyata sejarah seseorang, tingkat pen didikan, serta budaya yang ada disekitarnya berpengaruh terhadap bagaimana seseorang memberikan makna terhadap murabahah. Peneliti menemukan bahwa meski pun sudah berakad dengan LKS nasabah masih belum memiliki pemahaman terhadap akad yang dilakukan. Ulama pun yang begitu memahami hukum-hukum Islam tetapi tidak berhubungan dengan LKS ternyata juga kurang memahami makna murabahah, karena memang di dalam Al Qur'an dan Hadits tidak ada yang secara langsung menyebutkan tentang murabahah. Intinya adalah bahwa terdapat ulama yang tidak paham terhadap murabahah karena mereka tidak bekerjasama dengan LKS.

Disisi lain, manajemen BMT yang memang sejak kecil sudah menempuh 


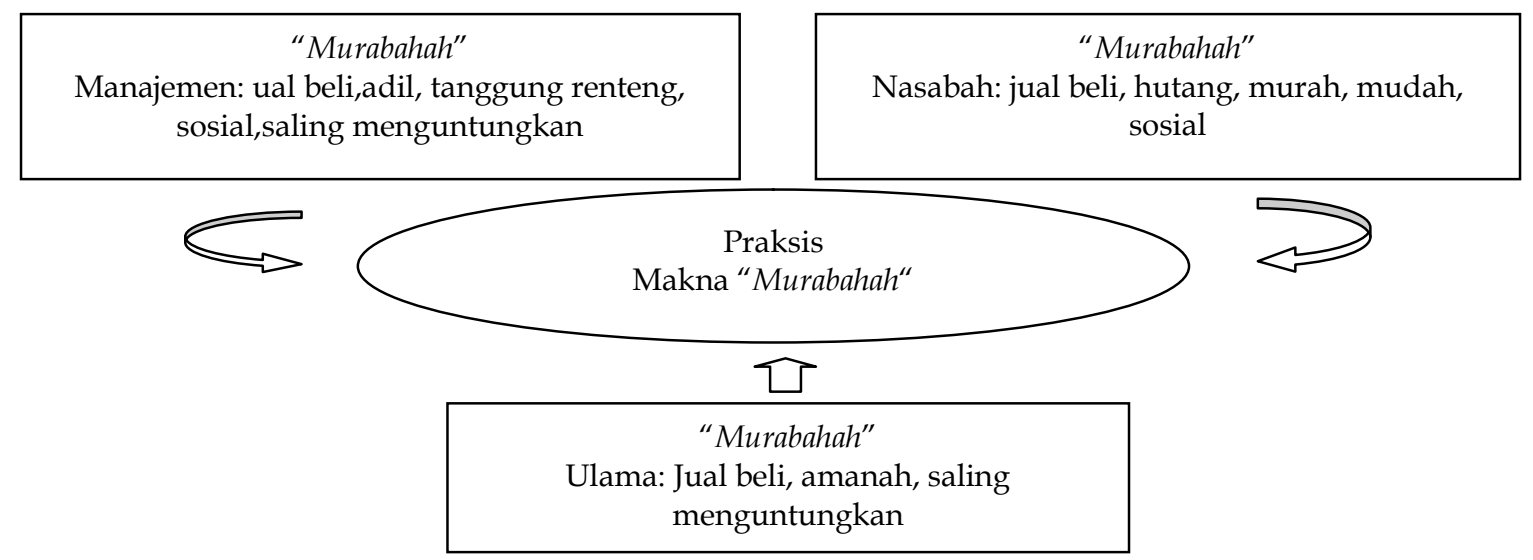

Gambar. 2

Trilogi Murabahah

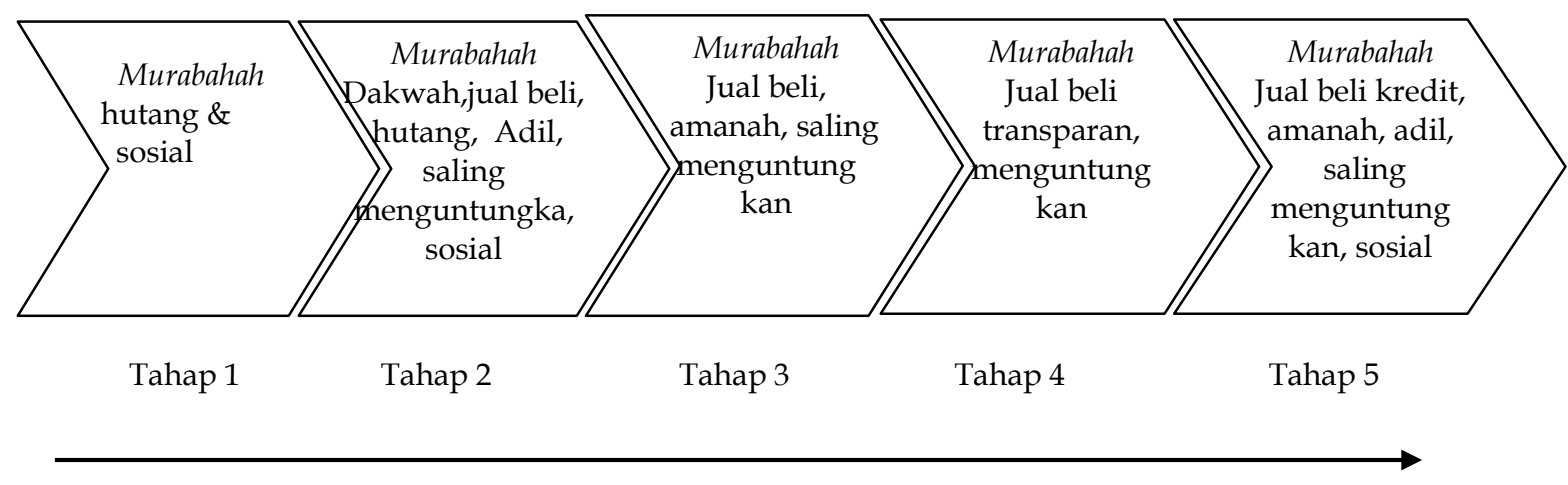

lebih syariah

\begin{tabular}{|l|l|l|l|l|lr|}
\hline Teoritis & KW 3 & KW 2 & & $\begin{array}{l}\text { KW 1 \& } \\
\text { DSN MUI }\end{array}$ & $\begin{array}{l}\text { Praksis } \\
\text { Hasil refleksi } \\
\text { peneliti } \\
\text { menautkan retelah } \\
\text { dan praktik }\end{array}$ & $\begin{array}{r}\text { teori } \\
\text { Empiris }\end{array}$ \\
\hline
\end{tabular}

Gambar 3

Sumber: Data olahan

Tahapan Makna Murabahah

pendidikan pondok memahami makna murabahah ketika mereka praktik melalui BMT. Berikut simpulan yang dapat peneliti berikan terkait bagaimana informan memak nai murabahah.

Temuan penelitian pada BMT, murabahah dimaknai sebagai kredit selayaknya hutang uang seperti pada bank konvensional, tetapi masih lebih humanis karena lebih adil, dan murah biaya yang dikenakan serta bertujuan sosial. Humanis memberi suatu pengertian bahwa murabahah bersifat manusiawi, sesuai fitrah manusia, dan dapat dipraktikkan sesuai dengan kapasitas yang dimiliki dan sesuai dengan budaya yang berlaku dimasyarakat setempat. $\mathrm{Na}$ mun demikian praktik yang ada pada BMT dianggap masih kurang syariah (KW 3), untuk itu diperlukan upaya yang serius untuk mengembalikan murabahah ke yang murni syariah (KW 1). 
Menurut pendapat ulama murabahah merupakan jual beli amanah yang saling menguntungkan.Dari dua sudut pandang tersebut yaitu praktisi dan ulama, terdapat perbedaan dari makna yang diberikan. Namun demikian, meskipun terdapat keragaman pemaknaan, kehadiran murabahah sebetulnya selaras dengan tujuan kehadiran akuntansi syariah seperti yang disampaikan Triyuwono (2011b) yaitu ingin membangkitkan kesadaran keTuhanan para penggunanya.

\section{Implikasi Penelitian}

Kesungguhan penelitian ini diharapkan memberi dampak atau implikasi tidak saja kepada peneliti sendiri tetapi juga pada pihak-pihak lain. Pertama, berkaitan dengan implikasi praktis bagi lembaga keuangan syariah. Dengan adanya makna yang ditemukan khususnya pemaknaan yang dilakukan oleh nasabah, menjadikan lembaga keuangan syariah lebih memperhatikan upaya pemahaman kepada nasabah yang lebih efektif terhadap setiap akad yang dilakukan khususnya murabahah serta meng amalkan nilai-nilai murabahah yang lebih humanis yaitu, amanah, adil, sosial, dan ikhlas.

Implikasi ke dua bagi DSN MUI, setidaknya dapat memahami bagaimana praktisi BMT memberi pemaknaan terhadap murabahah, khususnya dari sudut pandang manajemen dan nasabah BMT. Dengan demikian dapat dijadikan bahan evaluasi bagi praktik murabahah yang ternyata masih belum syariah.

Implikasi ke tiga bagi peneliti selanjutnya. Berdasarkan keterbatasan yang ada pada penelitian ini dapat dijadikan rujukan untuk melakukan penelitian berikutnya.

\section{Keterbatasan Penelitian dan Saran}

Kesempurnaan hanya milik Allah. Peneliti sudah berupaya maksimal untuk menyajikan pemaknaan murabahah dari sudut pandang praktisi dan ulama dengan menggunakan alat analisis hermeneutikaintensionalisme. Berbagai keterbatasan beri- kut merupakan bagian di luar kemampuan peneliti untuk bisa memenuhinya saat ini. Keterbatasan dalam penelitian ini, pertama adalah penggalian data yang kurang mendalam karena keterbatasan waktu. Masih sangat mungkin jika informasi digali lebih dalam, akan ditemukan makna-makna lain yang berbeda. Kedua, tidak semua ulama memahami tentang murabahah karena memang dalam Al-Quran dan Hadits tidak ada yang menyebutkan secara langsung tentang murabahah. Ketiga, lingkup penelitian ini hanya sebatas pada BMT dan informan pada penelitian ini terbatas pada ulama dan praktisi murabahah yaitu manajemen dan nasabah. Keempat, makna yang ditemukan saat ini juga merupakan salah satu keterbatasan dalam penelitian ini, karena dari makna yang ada akan memiliki konsekuensi logis dalam praktik.

Keterbatasan dalam penelitian ini merupakan suatu tantangan yang harus dijawab dalam penelitian selanjutnya. Mengingat bahwa penelitian ini masih banyak kekurangan, maka saran bagi penelitian selanjutnya adalah: pertama dapat menggali informasi lebih dalam dengan menambah waktu penelitian. Saran kedua, dapat melakukan penelitian di lembaga keuangan syariah yang berbeda dengan informan yang berbeda pula, misalnya dari pihak perpajakan dan praktisi dari perbankan syariah untuk DPS dan staff. Ketiga, penelitian berikutnya dapat menggunakan metode penelitian yang berbeda untuk mencari makna. Metode yang berbeda tentu akan menghasillkan makna yang berbeda pula. Dengan demikian khasanah keilmuan akuntansi syariah juga lebih beragam.

\section{DAFTAR PUSTAKA}

Abdurrahman, Y. 2012. Murabahah. http:// hizbuttahrir.or.id/murabahah/didownl oad, April 2012.

Ali, I. M. 2012. Memaknai Disclousure Laporan Sumber dan Penggunaan Dana Kebajikan (Qardhul Hasan) Bank Syariah. Jamal 3(2): 187-209. 
Aisjah, S. dan E. Kusumawati. 2011. Perspektif Kinerja Keuangan Bank Syariah di Indonesia. Jurnal Aplikasi Manajemen 9(4): 1237-1246

Ammar, A. 2007. Ekonomi-Syariah: Kembali Menyoal Sistem Murabahah Bank Syariah. Haramkah? http://www. mailarchive.com/ekonomi-syariah di download kamis, 5 April 2012.

Anggadini. 2010. Penerapan Margin Pembiayaan Murabahah. Majalah Ilmiah UNIKOM 9(2): 187-198.

Arsyianti, D. L dan S. I. Beik. 2010. Analisa Tingkat Pengembalian Pembiayaan Bank Syariah yang Lebih Tinggi Dibandingkan dengan Bank Konvensional: Studi kasus Malaysia. Bogor. FAI-UIKA

Astuti, W. T. 2007. Hubungan Kausal Kualitas Layanan, Loyalitas dan Komitmen Nasabah Pada Bank-bank Top Brand 2007 Di Yogyakarta. Jurnal Keuangan dan Perbankan 12(2): 296-307.

Djamhuri, A. 2011. Ilmu Pengetahuan Sosial dan Berbagai Paradigma dalam Kajian Akuntansi. Jurnal Akuntansi Multiparadigma 2(1): 147-185.

Ernawati, L dan U. Ludigdo. 2012. Eksplorasi Pemaknaan Murabahah. Jurnal Akuntansi Multiparadigma 3(2): Agustus 2012.

Fatahullah. 2008. Implementasi Prinsip Bagi Hasil dan Resiko di Perbankan Syariah (Studi di Perbankan Syariah cabang Mataram). UNDIP. Tesis

Fauzi, T. H. 2011. Manajerialisasi Dana Pihak Ketiga terhadap Peningkatan Laba Operasional pada PT (Persero) Bank Jabar Syariah Bandung. Jurnal Aplikasi Manajemen 9(3): 852-860.

Febrianty, A. 2009. Murabahah sebagai Bentuk Pembiayaan Personal pada Bank Syariah (Studi Kasus pada Bank Syariah Mandiri). Skripsi. Fak. Hukum Univ. Pembangunan Nasional "Veteran". Jakarta.

Grondin, J. 2012. Sejarah Hermeneutika: Dari Plato sampai Gadamer. Ar-Ruzz Media. Jogjakarta.

Kamayanti, A. 2008. Sejarah dan Perkembangan Hermeneutika serta Perannya dalam
Riset Akuntansi. Surabaya. STIE Mahardika.

Kholis, N. 2007. Kajian terhadap Kepatuhan Syariah dalam Praktik Pembiayaan di BMT Sleman Yogyakarta. Fenomena: 5(2): 123-140.

Kristiyanto, R. 2008. Konsep Pembiayaan dengan Prinsip Syariah dan Aspek Hukum dalam Pemberian Pembiayaan pada PT. BRI (Persero) Tbk. Kantor Cab. Syariah Semarang. Tesis. Magister Ilmu Hukum UNDIP.

Kusmiyati, A. N. S. 2007. Risiko Akad dalam Pembiayaan Murabahah pada BMT di Yogyakarta (dari Teori ke Terapan) Jurnal Ekonomi Islam: La_Riba 1(1): 27-41.

Lathif, A. A. 2012. Modifikasi Skema akad Murabahah dalam Praktik di Perbankann Syariah

Ludigdo, U dan F. R. Dhanias. 2011. Tanggungjawab Sosial Perusahaan Bank Syariah. Jurnal Aplikasi Manajemen 9(4): UM Press.

Ludigdo, U. 2007. Paradoks Etika Akuntan. Pustaka Pelajar. Yogyakarta.

Luqman. 2008. Kritik Terhadap Commodity Murabahah Product (CMP).http:// luqmannomic.wordpress.com/2008 di download Maret 2012.

Marwal, M. I. 2010. Rekonstruksi Murabahah Sebuah Ijtihad Solusi Pembiayaan. $h t t p: / / i s a 7695$.wordpress. com/2010.

Maulidin. 2003. Menafsirkan Hermeneutika. Lembaga Studi Agama dan Demokrasi (eLSAD). Gerbang. Surabaya.

Muhammad. R. 2008. Akuntansi Keuangan Syariah. Yogyakarta. P3EI Press.

Nelwan, F. S. 2010. Perbedaan Persepsi Pengenaan PPN atas Transaksi Murabahah. Tesis. FH UI.

Purnamasari, D dan Triyuwono, I. 2010. Tafsir Hermeneutika Intensionalisme Atas "Laba" Yayasan Pendidikan. Jurnal Akuntansi Multiparadigma. 1(3): 489-513.

Rahmawaty, A. 2007. Ekonomi Syari'ah: Tinjauan Kritis Produk Murabahah dalam Perbankan Syari'ah di Indo- 
nesia. Jurnal Ekonomi Islam: La_Riba I(2): 187-203.

Ricoeur, P. 2012. Teori Interpretasi. Jogyakarta. IRCiSod Banguntapan

Sari, D. P. 2010. Tafsir Hermeneutika Intensionalisme Atas "Laba" Yayasan Pendidikan. Jurnal Akuntansi Multiparadigma 1(3): 489-513.

Setiawan, A. B. 2006. Perbankan Syariah: Challenges dan Opportunity Untuk Pengembangan di Indonesia. Jurnal Kordinat VIII(1): April.

Setiawan, A. R. 2011. Tinjauan Paradigma Penelitian Merayakan Keragaman Pengembangan Ilmu Akuntansi. Jurnal Akuntansi Multiparadigma 2(3): 402-417.

Siregar, Mulya. 2002. Agenda Pengembangan Perbankan Syariah Untuk Mendukung Sistem Ekonomi Yang Sehat Di Indonesia: Evaluasi, Prospek dan Arah Kebijakan. IQTISAD Journal of Islamic Economics 3(1): 46-66.

Sopiah. 2008. Budaya Organisasi, Komitmen organisasional Pimpinan dan Pengaruh nya terhadap Kepuasan Kerja dan Kinerja Karyawan Bank. Jurnal Keuangan dan Perbankan 12(2): 308-317.

Suparto. 2008. Perilaku dan Kepuasan Pelanggan Bank Muamalat Indonesia
Cab. Surabaya. Jurnal Keuangan dan Perbankan 12(2): 331-341.

Suyanto dan Sutinah. 2005. Metode Penelitian Sosial. ISBN. 979-3465-92-1. Surabaya.

Triyuwono, I. 2011a. ANGELS: Sistem Penilaian Tingkat Kesehatan Bank Syariah. Jurnal Akuntansi Multiparadigma 2(1): 1-21. . 2011b. Mengangkat "sing Liyan" untuk Formulasi Nilai Tambah Syariah. Jurnal Akuntansi Multiparadigma 2(1): 1-21.

2006. Perspektif, Metodologi, dan Teori Akuntansi Syariah. PT. Raja Grafindo Persada. Jakarta.

Tuasikal, M. A. 2012. Murabahah yang Mengandung Riba. http: //rumaysho. com/hukumislam/muamalah/367. di down load Februari 2012.

Usmani, M. T. 2003. Murabahah. An Online Publication by Accountancy.com. Page of 30

Yaya, R, Martawireja, A. E, dan Abdurahim, A. 2009. Akuntansi Perbankan Syariah Teori dan Praktik Kontemporer. Jakarta. Salemba Empat.

Yulianti, R. T. 2007. Pola Ijtihad Fatwa Dewan Syari'ah Nasional MUI tentang Produk Perbankan Syariah. Jurnal Ekonomi Islam La_Riba. 1(1): 57-75. 